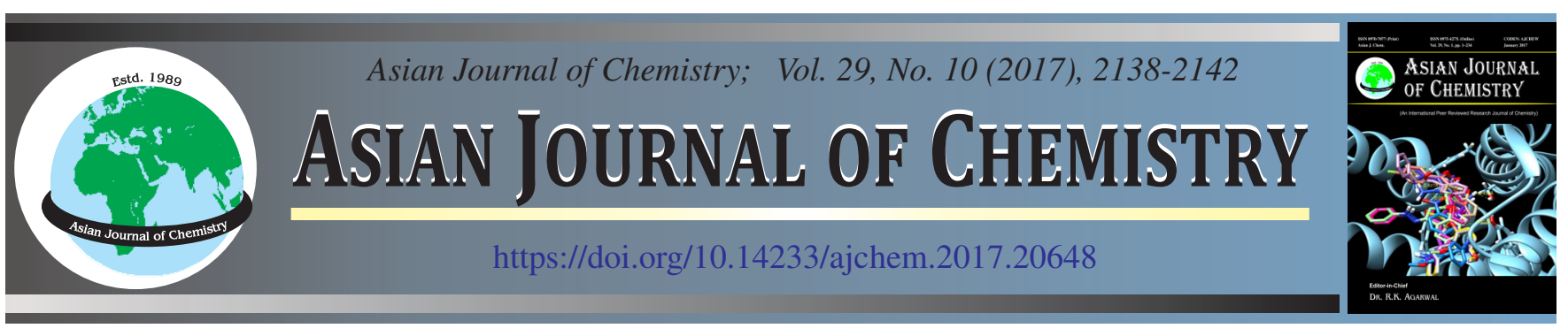

\title{
Minerals and Arsenic Composition of Twenty Five Indigenous Leafy Vegetables of Jorhat District of Assam State, India
}

\author{
B.H. ChOudhury ${ }^{1, *}$, A.M. BARUAH ${ }^{2}$ and P. Das ${ }^{2}$
}

${ }^{1}$ Department of Biochemistry and Agricultural Chemistry, B.N. College of Agriculture, Chariali-784 176, India ${ }^{2}$ Department of Biochemistry and Agricultural Chemistry, Assam Agricultural University, Jorhat-785 013, India

*Corresponding author: E-mail: bh_choudhury@ rediffmail.com

Keywords: Indigenous leafy vegetables, Wild, Macro minerals, Micro minerals, Arsenic, Edible plants.

\section{INTRODUCTION}

Traditional vegetables must be associated with traditional production systems, local knowledge and usually have a long history of local usage. Traditional leafy vegetables are those plants whose leaves are socially accepted, used and consumed for various purposes such as food, nutritional and medicinal values and additives. Wild leafy vegetables are generally ignored by the people in the developed nations which are subsistence agriculture in developing countries especially in the food insecure regions. Indigenous people in remote areas had deep knowledge about the use of these wild species as food especially during the period of drought, famine and civil unrest. The knowledge of these wild species could be considered as the most important determinant for an individual or a family to maintain their nutritional well-being to overcome malnourishment. Moreover, these wild vegetables have an important socio-economic impact by their use in medicines, foods, fibers and cultural ceremonies [1]. In recent decades, emphasis has been given on wild plant species for their possible nutritional and medicinal values to broaden the diversity of human diet [2,3]. This is because people are more concern about the benefits of modern agricultural technology and marketing of cultivate plant types with high productivity which results in massive lost of biodiversity.

Moreover, reduction of genetic diversity of plants species in human diets results the high dietary selectivity practice which cause difficulty in getting full complement of essential nutrients through daily diet, lead to malnutrition and undernutrition [4]. Furthermore, most of the foods consumed by people have been "upgraded" through refined and modified processes such as cooking, crushing, leaching and husking that causes reduction or removal of certain essential nutrients from the food [5].

On the other hand, modern research on wild leafy vegetables in different regions find out that most of these wild greens have great nutritional values and antioxidant properties, which are comparable to those commercially cultivated vegetables $[3,6,7]$. Glew et al. [6] reported that three usually consumed edible wild plants by the indigenous people in Niger (West Africa's Sahara region) have great influence on the nutritional status of local people due to their proportions of essential amino acids favourably adhering to the World Health Organization (WHO) standard. Besides, Maisuthisakul et al. [7] found that the indigenous chewing plants in Thailand contained great amount of phenolics and flavonoids responsible for antiradical activities. In other words, wild leafy vegetables often considered as the 'weed of agriculture' are now not only famine foods or wild foods in developing country, but also serve as a source of functional nutrients.

Leafy vegetables play a major role in the Assamese diet, probably due to the influence of traditional herbal medicine, easy accessibility and low cost. Further, green leaves are 
considered as a main source of vitamins, minerals and fibre for local consumers. The use of wild plants as leafy vegetables is very common in Assam. Some of these species are also very popular but some species are sought-after more than others. In Assam they appear as uncultivated and semi cultivated crops or weedy and wild plants, with ecological, social and cultural values, playing a significant role in the daily food and nutritional requirement of local people mainly in the rural. However, there is no significant basis or reports in the modern literature regarding its macro-micro minerals and arsenic composition. That is why the present study was aimed to evaluate the macromicro minerals and arsenic composition of the indigenous leafy vegetables of Jorhat district of Assam.

\section{EXPERIMENTAL}

Twenty five indigenous plant materials viz. Bacopa monnieri, Leucas longifolia, Enhydra fluctuans, Erynginum foetidum, Amaranthus spinosus, Pteridium aquilinum, Amaranthus viridis, Hydrocotyl rotundifolia, Alternanthera sessilis, Paederia foetida; Eclipta alba, Houttuynia cordata, Talinum triangularae, Polygonum chinense, Oxalis corniculata, Oldenlandia corymbosa, Malva sylvestris, Chrysopagon coroneriam, Trigonella foenum-graecum, Basella rubra, Chenopodium album, Stellaria media, Basella alba, Centalla asiatica and Oxalliis acetosella were collected from various places of Jorhat district on the basis of their popularity of use by the people of Jorhat district. These plants were planted in pot in the Department of Biochemistry and Agricultural Chemistry, Assam Agricultural University, Jorhat, India for investigation. Young tender edible parts of these plant species were collected and dried under sunshine and after drying milling were done in wily mill (IKON, Dehli). The dry powder was used for investigation.

Soil $\mathrm{pH}$ was determined by Potentiometer Method in 1:2.5 soil water ratio using Systronic $\mu$-pH System 361 [8]. Organic carbon of the soil was determined by Walkey and Black wet digestion method [9]. Available nitrogen in the soil sample was determined by alkaline potassium permanganate $\left(\mathrm{KMnO}_{4}\right)$ method [10]. Available phosphorus in the soil was determined by Bray's method [11] using UV-visible spectrophotometer. Available potassium in the soil was determined by ammonium acetate extraction [8] using flame photometer, Systronic, Model-130. The nitrogen content was determined by microKjeldahl method [12]. The phosphorous content of the indigenous leafy vegetables was determined by Fiske and Sukhrow method [13]. The mineral solution prepared as per method [14] was used for the estimation of potassium, sodium and calcium content by flame photometry method [15]. The estimation of copper, zinc, manganese and arsenic were done from mineral solution by atomic absorption spectrophotomatric method.

\section{RESULTS AND DISCUSSION}

The research findings of soil analysis, macro minerals, micro minerals and arsenic content are presented in the Tables 1 and 2 , respectively.

Chemical analysis of soil: The $\mathrm{pH}$ value was found 6.2 which are ideal for the growth of microbes. Similar results
TABLE-1 FEW CHEMICAL PARAMETERS OF SOIL

\begin{tabular}{lc}
\hline \multicolumn{1}{c}{ Parameters } & Value \\
\hline $\mathrm{pH}$ & 6.2 \\
Organic carbon (\%) & 0.834 \\
$\mathrm{Av}-\mathrm{N}\left(\mathrm{kg} \mathrm{ha}^{-1}\right)$ & 492.1 \\
$\mathrm{Av}-\mathrm{P}_{2} \mathrm{O}_{5}\left(\mathrm{~kg} \mathrm{ha}^{-1}\right)$ & 29.8 \\
$\mathrm{Av}-\mathrm{K}_{2} \mathrm{O}\left(\mathrm{kg} \mathrm{ha}^{-1}\right)$ & 185.9 \\
\hline
\end{tabular}

were reported by Karmakar [16]. The organic carbon (OC) value was found $0.834 \%$ which is ideal source for plant nutrients. These are in agreement with the report of Chakraborty et al. [17]. The available- $\mathrm{N}\left(\mathrm{kg} \mathrm{ha}^{-1}\right)$ value was found 492.1 which are in agreement with the report of Baruah et al. [18]. The available- $\mathrm{P}_{2} \mathrm{O}_{5}\left(\mathrm{~kg} \mathrm{ha}^{-1}\right)$ value was found 29.8. Similar results (26.8 kg/ha) are reported by Das et al. [19]. The available$\mathrm{K}_{2} \mathrm{O}\left(\mathrm{kg} \mathrm{ha}^{-1}\right)$ value was found 185.9 which are almost similar with values $(173.9 \mathrm{~kg} / \mathrm{ha})$ obtained by Das et al. [19]. This may be due to farmy yard manure added to the soil.

Macro mineral content: Human body needs many minerals that are called essential minerals. Essential minerals are macro minerals and micro minerals. A balanced diet provides all the essential minerals. Minerals needs for healthy growth and metabolism. Minerals work in conjunction with vitamins to perform many bodily functions like bone formation, heart function and digestion. Macro minerals like nitrogen, phosphorous, potassium, sodium and calcium have been determined in different indigenous leafy vegetables.

The nitrogen content of the selected indigenous leafy vegetables is ranged from $2.71-7.10 \%$. The indigenous leafy vegetables Pteridium aquilinum $(7.10 \%)$ has the highest nitrogen content and Paederia foetida $(2.71 \%)$ has lowest nitrogen content. The results are comparable with the results obtained by Kamga et al. [20] in Nightshade contained the highest level of total $\mathrm{N}(6.11 \pm 0.636 \%)$ on dry weight basis. Jain et al. [21] reported nitrogen content in Oxalis corniculata leaves $3.56 \%$ and Jimoh et al. [22] reported that Amaranthus asper leaves contained $1.78 \mathrm{mg} / 100 \mathrm{~g}$ (dry weight basis) nitrogen.

The phosphorous contents of different leafy vegetables in this study is ranged from $38.0-603.0 \mathrm{mg} / 100 \mathrm{~g}$. Polygonum chinense $(603.0 \mathrm{mg} / 100 \mathrm{~g})$ has the highest phosphorous content and Oxallis acetosella (38.0 mg/100 g) has lowest phosphorous content. The results are comparable with the results obtained by Kamga et al. [20] which varies from $420 \mathrm{mg}$ to $540 \mathrm{mg}$ / $100 \mathrm{~g}$ on dry weight basis in few green leafy vegetables; Zeghichi et al. [23] reported that S. pecten-veneris contain $518 \mathrm{mg} / 100 \mathrm{~g}$ of phosphorous and Caunii et al. [24] reported that the phosphorous content in four green leafy vegetables varies from $23 \mathrm{mg}$ to $66 \mathrm{mg} / 100 \mathrm{~g}$ on dry weight basis. Phosphorus is essential component of bone. Deficiency of phosphorus-calcium balance result in osteoporosis, arthritis, pyorrhea, rickets and tooth decay.

The potassium contents of different leafy vegetables is ranged from $0.64-9.58 \%$. Talinum triangularae $(9.58 \%$ ) has the highest potassium content and Basella rubra has the lowest $(0.64 \%)$ potassium content. Potassium is a key circulating electrolyte involved in the regulation of ATP dependent channels along with sodium. These channels are the $\mathrm{Na}^{+} / \mathrm{K}^{+}$-ATPases 
TABLE-2

MACRO MINERAL CONTENT ON DRY WEIGHT BASIS OF INDIGENOUS

LEAFY VEGETABLES OF JORHAT DISTRICT, ASSAM (g \% AND mg \%)

\begin{tabular}{|c|c|c|c|c|c|c|c|c|c|c|c|c|}
\hline \multirow{2}{*}{$\begin{array}{l}\text { S. } \\
\text { No. }\end{array}$} & \multirow[b]{2}{*}{ Local name } & \multirow[b]{2}{*}{ Scientific name } & \multicolumn{5}{|c|}{$\mathrm{g} \%$} & \multicolumn{5}{|c|}{$\mathrm{mg} \%$} \\
\hline & & & $\mathrm{N}$ & $\begin{array}{c}\mathrm{P} \\
(\mathrm{mg} \%)\end{array}$ & $\mathrm{K}$ & $\mathrm{Na}$ & $\mathrm{Ca}$ & $\mathrm{Fe}$ & $\mathrm{Cu}$ & $\mathrm{Zn}$ & $\mathrm{Mn}$ & As \\
\hline 1 & Brahmi & Bacopa monnieri & 3.92 & 91.00 & 1.09 & 231.00 & 0.20 & 51 & 0.016 & 0.02 & 35.67 & 1.20 \\
\hline 2 & Doron & Leucas longifolia & 4.26 & 119.00 & 3.87 & 132.67 & 1.20 & 151 & 0.003 & 0.046 & 44.00 & 0.27 \\
\hline 3 & Helosi sak & Enhydra fluctuans & 5.38 & 92.00 & 6.06 & 233.00 & 0.90 & 31 & 0.020 & 0.055 & 39.67 & 0.30 \\
\hline 4 & Mandhania & Erynginum foetidum & 5.10 & 119.67 & 4.54 & 156.33 & 0.80 & 51 & 0.009 & 0.015 & 24.00 & 0.60 \\
\hline 5 & Hatikhotora & Amaranthus spinosus & 5.91 & 129.00 & 5.28 & 132.00 & 1.30 & 31 & 0.019 & 0.019 & 59.00 & 0.00 \\
\hline 6 & Dhekia & Pteridium aquilinum & 7.10 & 130.67 & 4.39 & 92.00 & 0.30 & 31 & 0.043 & 0.016 & 27.67 & 0.00 \\
\hline 7 & Khotora & Amaranthus viridis & 5.00 & 100.00 & 3.69 & 126.33 & 1.20 & 401 & 0.010 & 0.009 & 76.33 & 0.80 \\
\hline 8 & Saru Manimoni & Hydrocotyl rotundifolia & 3.94 & 95.00 & 4.02 & 116.33 & 1.50 & 71 & 0.015 & 0.077 & 55.00 & 0.6 \\
\hline 9 & Matikandori & Alternanthera sessilis & 4.44 & 143.33 & 6.34 & 155.00 & 0.70 & 139 & 0.016 & 3.73 & 12.00 & 0.00 \\
\hline 10 & Bhedailata & Paederia foetida & 2.71 & 102.67 & 0.70 & 52.00 & 2.10 & 41 & 0.007 & 0.013 & 25.00 & 1.20 \\
\hline 11 & Keheraj & Eclipta alba & 3.80 & 78.00 & 3.58 & 105.00 & 1.00 & 51 & 0.015 & 6.29 & 72.33 & 0.00 \\
\hline 12 & Masundori & Houttuynia cordata & 2.82 & 109.67 & 3.56 & 116.67 & 1.00 & 91 & 0.013 & 0.088 & 82.00 & 0.00 \\
\hline 13 & Pirali paleng & Talinum triangularae & 4.79 & 86.00 & 9.58 & 186.00 & 0.40 & 51 & 0.016 & 0.062 & 84.67 & 0.60 \\
\hline 15 & SaruTengesi & Oxalis corniculata & 3.13 & 142.00 & 3.76 & 136.00 & 0.70 & 61 & 0.005 & 0.015 & 48.00 & 0.00 \\
\hline 16 & Bonjaluk & Oldenlandia corymbosa & 2.83 & 134.00 & 1.27 & 101.33 & 1.20 & 91 & 0.007 & 0.074 & 50.33 & 0.70 \\
\hline 17 & Laffa & Malva sylvestris & 5.11 & 120.67 & 3.66 & 102.00 & 1.50 & 51 & 0.013 & 0.009 & 32.00 & 0.30 \\
\hline 18 & Baburi & Chrysopagon coroneriam & 5.17 & 104.33 & 4.93 & 186.33 & 0.80 & 221 & 0.013 & 0.019 & 132.00 & 0.77 \\
\hline 19 & Methi & $\begin{array}{l}\text { Trigonella foenum- } \\
\text { graecum }\end{array}$ & 5.75 & 62.67 & 2.50 & 186.00 & 1.10 & 51 & 0.004 & 0.060 & 70.00 & 0.80 \\
\hline 20 & Puroi (red) & Basella rubra & 2.95 & 115.00 & 0.64 & 172.00 & 1.50 & 31 & 0.006 & 0.018 & 13.33 & 0.00 \\
\hline 21 & Jilmil & Chenopodium album & 5.91 & 129.00 & 5.62 & 153.33 & 1.70 & 91 & 0.015 & 0.031 & 75.67 & 0.70 \\
\hline 22 & Morolia & Stellaria media & 4.37 & 108.33 & 2.26 & 92.00 & 1.40 & 121 & 0.006 & 6.08 & 41.00 & 0.00 \\
\hline 23 & Puroi (green) & Basella alba & 4.51 & 108.00 & 0.86 & 194.67 & 1.50 & 106 & 0.013 & 7.55 & 70.00 & 1.70 \\
\hline 24 & Bor Manimoni & Centalla asiatica & 2.55 & 95.00 & 1.66 & 82.33 & 1.00 & 101 & 0.005 & 0.025 & 68.67 & 0.00 \\
\hline \multirow[t]{3}{*}{25} & Bor Tangeshi & Oxallis acetosella & 5.11 & 38.00 & 2.24 & 92.67 & 0.80 & 151 & 0.011 & 0.022 & 69.00 & 0.00 \\
\hline & & SED ( $( \pm)$ & 0.06 & 1.32 & 0.10 & 1.65 & 0.41 & 0.84 & 0.003 & 0.02 & 2.28 & 0.06 \\
\hline & & $\mathrm{CD}$ at $5 \%$ & $0.10 *$ & $2.27 *$ & $0.027 *$ & $2.82 *$ & $0.70 *$ & $1.44^{*}$ & $0.004 *$ & $0.03 *$ & $3.90 *$ & $0.10 *$ \\
\hline
\end{tabular}

and their primary function is in the transmission of nerve impulses in the brain. The results are slightly higher than obtained by other authors. These results are comparable with the results obtained by Grace et al. (4.90 to $6.11 \%$ ) [25] and Kamga et al. (3.08 to $5.86 \%$ ) [20].

The sodium contents of different leafy vegetables is ranged from 52.0-233.0 \% . The indigenous leafy vegetable Enhydra fluctuans $(233.0 \%)$ has the highest sodium content and Paederia foetida $(52.0 \%)$ has the lowest sodium content. Sodium is involved in the regulation of plasma volume, acid-base balance, nerve and muscle contraction [26]. The results are comparable with the results obtained by Gupta et al. [27] in Celosia argentea (240.6 mg \%) and Centella asiatica had (107.8 mg $\%$ ) and Zeghichi et al. [23] in S. pecten-veneris (381 mg \% and $662 \mathrm{mg} \%$ ) in Pakistan and Greece, respectively.

The calcium contents of different leafy vegetables is ranged from 200.7-2104.96\%. Paederia foetida $(2104.96 \%)$ has the highest calcium content and Bacopa monnieri (200.7\%) has lowest calcium content. Calcium is an important constituent of bones and teeth. It involved in regulation of nerve and muscle function. In blood coagulation, calcium activates the conversion of pro-thrombin to thrombin. The results are comparable with the results obtained by Grace et al. [25] in Chenopodium album and Solanum nigram which was $18213.2 \mathrm{mg} / 100 \mathrm{~g}$ and 16890.0/100 g of calcium, respectively and Kamga et al. [20] reported that calcium content varies from $1150 \mathrm{mg}$ to 2690 $\mathrm{mg} / 100 \mathrm{~g}$ in three leafy vegetables.
Micro mineral and arsenic content: Micro minerals are the part of enzymes, hormones and cells in human body. Insufficient intake of micro minerals can cause symptoms of nutritional deficiency. Arsenic is one of the most important environmental pollutants and persistent bioaccumulative carcinogen. Micro-minerals like iron, copper, zinc, manganese and heavy metal like arsenic have been determined in different indigenous leafy vegetables which are vital for maintaining health.

The iron contents of different leafy vegetables is ranged from 31.0-401.0 mg/100 g. The indigenous leafy vegetables Amaranthus viridis $(401.0 \mathrm{mg} / 100 \mathrm{~g}$ ) has the highest iron content and Enhydrafluctuans, Amaranthus spinosus, Pteridium aquilinum and Basella rubra $(31.0 \mathrm{mg} / 100 \mathrm{~g})$ has lowest iron content. The results are comparable with the results obtained by Grace et al. [25] in Chenopodium album and Solanum nigram contains $120.4 \mathrm{mg} / 100 \mathrm{~g}$ and 177.1/100 $\mathrm{g}$ of iron on dry weight basis, respectively; Singh et al. [28] found total iron content of selected green leafy vegetables ranged from 22.3 to 84.4 $\mathrm{mg} / 100 \mathrm{~g}$ on a dry matter basis and Kamga et al. [20] reported that iron content varies from $3.34 \mathrm{mg}$ to $38.79 \mathrm{mg} / 100 \mathrm{~g}$ on dry weight basis in three leafy vegetables. Iron is an important trace element in the human body, it plays crucial roles in haemopoiesic, control of infection and cell mediated immunity [29]. The deficiency of iron has been described as the most prevalent nutritional deficiency and iron deficiency anemia is estimated to affect more than one billion people worldwide [30]. The 
consequences of iron deficiency include reduced work capacity, impairments in behaviour and intellectual performance and decrease resistance to infection [31].

The copper contents of different leafy vegetables is ranged from 0.020-0.003\%. Enhydra fluctuans, Polygonum chinense $(0.020 \%)$ has the highest copper content and Leucas longifolia $(0.003 \%)$ has lowest copper content. Copper is required for the proper growth, development, maintenance of bone, brain, heart and many other body organs. The results are comparable with the results obtained by Grace et al. [25] in Chenopodium album and Solanum nigram contains $9.1 \mathrm{mg} / 100 \mathrm{~g}$ and 11.2/ $100 \mathrm{~g}$ of copper on dry weight basis respectively; Singh et al. [28] reported that copper content of green leafy vegetables ranged from 0.8 to $1.0 \mathrm{mg} / 100 \mathrm{~g}$ and Zeghichi et al. [23] reported that $S$. pecten-veneris contain copper 54 and 1.71 $\mathrm{mg} / 100 \mathrm{~g}$ in Pakistan and Greece, respectively.

The zinc contents of different leafy vegetables is ranged from 7.55-0.013 mg/100 g. Basella alba $(7.55 \mathrm{mg} / 100 \mathrm{~g})$ has the highest zinc content and Paederia foetida $(0.013 \mathrm{mg} / 100$ g) has lowest zinc content. Zinc has a role in the regulation of blood glucose levels via insulin function. Zinc is an essential micronutrient for human growth and immune functions [32]. The results are comparable with the results obtained by Grace et al. [25] in Chenopodium album and Solanum nigram contains $23.0 \mathrm{mg} / 100 \mathrm{~g}$ and $26.1 \mathrm{mg} / 100 \mathrm{~g}$ of zinc on dry weight basis respectively; Kamga et al. [20] reported that zinc content varies from $0.021 \mathrm{mg}$ to $0.102 \mathrm{mg} / 100 \mathrm{~g}$ on dry weight basis in three leafy vegetables and Afolayan and Jimoh [3] reported that zinc contents of four green leafy vegetables ranged from 4.2 to 5.5 $\mathrm{mg} / 100 \mathrm{~g}$.

The manganese contents of different leafy vegetables is ranged from 132.00-12.00 mg/100 g. Chrysopagon coroneriam $(132.00 \mathrm{mg} / 100 \mathrm{~g})$ has the highest manganese content and Alternanthera sessilis (12.00 mg/100 g) has lowest manganese content. Very low intakes of manganese are associated with poor bone formation. Manganese is a required co-factor for an enzyme prolidase required to make collagen. It is also a co-factor for an enzyme manganese superoxide dismutase (MnSOD), is a potent antioxidant. The results are comparable with the results obtained by Afolayan and Jimoh [3] in four green leafy vegetables ranged from 8.3 to $11.8 \mathrm{mg} / 100 \mathrm{~g}$; Singh et al. [28] in green leafy vegetables ranged from 1.8 to 10.2 $\mathrm{mg} / 100 \mathrm{~g}$ and Asaolu et al. [33] in some green leafy vegetables ranges between $2.54 \mathrm{mg} / 100 \mathrm{~g}$ and $10.06 \mathrm{mg} / 100 \mathrm{~g}$.

The arsenic contents of different leafy vegetables is ranged from $1.70-0.0 \mathrm{mg} / 100 \mathrm{~g}$. Basella alba $(1.70 \mathrm{mg} / 100 \mathrm{~g})$ has the highest arsenic content and Amaranthus spinosus, Pteridium aquilinum, Alternanthera sessilis, Eclipta alba, Houttuynia cordata, Oxalis corniculata, Basella rubra, Stellaria media, Centalla asiatica, Oxalllis acetosella $(0.0 \mathrm{mg} / 100 \mathrm{~g})$ has lowest arsenic content. Arsenic affect young nervous system of the child and thereby adversely affecting the intellectual development and subsequent behaviour of the child [25]. The results are comparable with the results obtained by Grace et al. [25] in Chenopodium album and Solanum nigram contains $1.8 \mathrm{mg} /$ $100 \mathrm{~g}$ and $1.9 \mathrm{mg} / 100 \mathrm{~g}$ of arsenic on dry weight basis, respectively and Jahanara [34] in few green leafy vegetables ranges between 0.047 to $0.324 \mathrm{mg} / 100 \mathrm{~g}$.
The variation in the macrominerals, microminerals and arsenic constituents of wild leafy vegetables may be due to the stage of maturity of the plant, conditions of growth, soil fertility and environmental conditions of the plant species.

\section{Conclusion}

Indigenous leafy vegetables considered as 'weed of agriculture' and famine foods or wild foods in developing country which serve as a source of functional nutrients are rich source of macro-micronutrient and very less contamination by arsenic.

\section{ACKNOWLEDGEMENTS}

The authors express their gratitude to Department of Biochemistry and Agricultural Chemistry, Assam Agricultural University, Jorhat, India for providing the research facilities to carry out this research work.

\section{REFERENCES}

1. M.V. Flyman and A.J. Afolayan, S. Afr. J. Bot., 72, 492 (2006); https://doi.org/10.1016/j.sajb.2006.02.003.

2. M.V. Flyman and A.J. Afolayan, Int. J. Food Sci. Nutr., 58, 419 (2007); https://doi.org/10.1080/09637480701253417.

3. A.J. Afolayan and F.O. Jimoh, Int. J. Food Sci. Nutr., 60, 424 (2009); https://doi.org/10.1080/09637480701777928.

4. K. Milton, Comp. Biochem. Physiol. Part A, 136, 47 (2003); https://doi.org/10.1016/S1095-6433(03)00084-9.

5. G.M. Legwaila, W. Mojeremane, M.E. Madisa, R.M. Mmolotsi and M. Rampart, J. Hortic. For., 3, 171 (2009).

6. R. Glew, D. Vanderjagt, L.T. Chuang, Y.S. Huang, M. Millson and R. Glew, Plant Foods Hum. Nutr., 60, 187 (2005); https://doi.org/10.1007/s11130-005-8616-0.

7. P. Maisuthisakul, M. Suttajit and R. Pongsawatmanit, Food Chem., 100, 1409 (2007); https://doi.org/10.1016/j.foodchem.2005.11.032.

8. M.L. Jackson, Soil Chemical Analysis, Prentice Hall of India Private Limited, New Delhi, India (1973).

9. A. Walkley and C.A. Black, Soil Sci., 37, 29 (1934); https://doi.org/10.1097/00010694-193401000-00003.

10. B.V. Subbiah and G.L. Asija, Curr. Sci., 25, 259 (1956).

11. R.H. Bray and L.T. Kurtz, Soil Sci., 59, 39 (1945); https://doi.org/10.1097/00010694-194501000-00006.

12. AOAC, Washington, D.C. (1965).

13. D.H. Fiske and Y. Sukhrow, J. Biol. Chem., 66, 375 (1925).

14. AOAC, Washington, D.C., edn 11 (1970).

15. A.M. Baruah and R.C. Borah, Assam Agricultural University, Jorhat, p. 41 (1998).

16. R.M. Karmakar, Ph.D. Thesis, Genesis and Classification of Soils of Northern Brahmaputra Valley of Assam, IARI, New Delhi, India (1985).

17. D.N. Chakraborty and J.P. Baruah, Indian J. Agric. Chem., 17, 17 (1984).

18. B.K. Baruah, B. Das, C. Medhi and A.K. Misra, J. Chem., Article ID 983297 (2013); https://doi.org/10.1155/2013/983297.

19. B.K. Das, B.H. Choudhury and K.N. Das, Int. J. Adv. Res. Technol., 2, 190 (2013).

20. R.T. Kamga, C. Kouame, A.R. Atangana, A.T. Chagomoka and R. Ndango, J. Hortic. Res., 21, 99 (2013); https://doi.org/10.2478/johr-2013-0014

21. A.K. Jain, P. Tiwari and M. Bashir, Bot. Res. Int., 3, 35 (2010).

22. F.O. Jimoh, A.A. Adedapo, A.A. Aliero, S. Koduru and A.J. Afolayan, Open Complement. Med. J., 2, 7 (2010); https://doi.org/10.2174/1876391X01002010007.

23. S. Zeghichi, S. Kallithraka, A.P. Simopoulos and Z. Kypriotakis, World Rev. Nutr. Diet., 91, 22 (2003); https://doi.org/10.1159/000069928.

24. A. Caunii, R. Cuciureanu, A.M. Zakara, E. Tonea and C. Giuchici, Stud. Univ. Vasila Goldis Seria Stiintele Vietii, 20, 45 (2010).

25. G. Grace, G.M. Bomikazi, N. Collise and G. Nomalungelo, International Proceedings of Chemical, Biological \& Environmental Engineering, 53, 93 (2013). 
26. E.O. Akpanyung, Pak. J. Nutr., 4, 327 (2005); https://doi.org/10.3923/pjn.2005.327.329.

27. S. Gupta, A. Jyothi Lakshmi, M.N. Manjunath and J. Prakash, LWTFood Sci Technol., 38, 339 (2005); https://doi.org/10.1016/j.1wt.2004.06.012.

28. G. Singh, A. Kawatra and S. Sehgal, Plant Foods Hum. Nutr., 56, 359 (2001); https://doi.org/10.1023/A:1011873119620.

29. P. Bhaskaram, Br. J. Nutr., 85, S75 (2001); https://doi.org/10.1079/BJN2000297.
30. F. Trowbridge and M. Martorell, J. Nutr., 85, 875 (2002).

31. B.M. Dioxon and E.M. Haris, Nigeria Food Consumption and Nutrition Survey, 2001-2003, (2004).

32. R.E. Black, J. Nutr, 133, 1485S (2003).

33. S.S. Asaolu, O.S. Adefemi, I.G. Oyakilome, K.E. Ajibulu and M.F. Asaolu, J. Food Res., 1, 214 (2012); https://doi.org/10.5539/jfr.v1n3p214.

34. L. Jahanara, Bangladesh J. Pharmacol., 2, 88 (2007). 